\title{
Maternal oxygen exposure may not change umbilical cord venous partial pressure of oxygen: non-random, paired venous and arterial samples from a randomised controlled trial
}

Yunhai Chuai ${ }^{1,2+} \mathbb{D}$, Wen Jiang ${ }^{2+}$, Xiaobin $\mathrm{Xu}^{3+}$, Aiming Wang ${ }^{2}$, Yuanqing $\mathrm{Yao}^{1,4^{*}}$ and Lei Chen ${ }^{1,2^{*}}$

\begin{abstract}
Background: Despite the widespread use of oxygen $\left(\mathrm{O}_{2}\right)$ in intrauterine resuscitation, the obstetric scientists' understanding of $\mathrm{O}_{2}$ therapy is full of contradictions. We tested the hypothesis that higher maternal arterial partial pressure of oxygen $\left(\mathrm{PO}_{2}\right)$ is associated with higher umbilical cord venous $\mathrm{PO}_{2}\left(\mathrm{UvPO}_{2}\right)$.

Methods: This is a planned secondary analysis of a randomised controlled trial (RCT), 443 normal women were 1:1 randomly allocated to receive $2 \mathrm{~L} / \mathrm{min} \mathrm{O}_{2}$ or room air from the onset of second stage to delivery. We reported that maternal $2 \mathrm{~L} / \mathrm{min} \mathrm{O}_{2}$ exposure cannot affect the umbilical cord arterial pH or the fetal heart rate (FHR) pattern. In 217 non-random samples, we found $2 \mathrm{~L} / \mathrm{min} \mathrm{O}_{2}$ exposure increased the maternal arterial $\mathrm{PO}_{2}$ to the median $150 \mathrm{mmHg}$ (hemoglobin would be saturated). The primary outcome for this analysis was $\mathrm{UVPO}_{2}$ in these non-random samples.

Results: There were no significant differences between the $\mathrm{O}_{2}$ group $(N=107)$ and the control group $(N=110)$ in the $\mathrm{UvPO}_{2}$ (median 30.2, interquartile 25.4-35.2 versus median 28.3, interquartile 23.4-35.3, $\mathrm{mmHg}, P=0.379$ ). There were also no significant differences between room air and different percentiles of $\mathrm{O}_{2}$ exposure duration $(<25$ th $\geqq 25$ th $<$ 50th, $\geqq 50$ th $<75$ th, $\geqq 75$ th percentile) in the $\mathrm{UVPO}_{2}$.
\end{abstract}

Conclusions: Maternal $\mathrm{O}_{2}$ exposure at super-physiological levels (median arterial blood $\mathrm{PO}_{2} 150 \mathrm{mmHg}$ ) in normal labor may not change the $\mathrm{UvPO}_{2}$.

Clinical trial registration: ClinicalTrials.gov NCT02221440, first posted in 20 August 2014.

Keywords: Low flow oxygen, The second stage of labor, Umbilical cord venous $\mathrm{PO}_{2}$

\footnotetext{
*Correspondence: wangyh85@foxmail.com; 3313400243@qq.com

${ }^{\dagger}$ Yunhai Chuai, Wen Jiang and Xiaobin Xu contributed equally to this work.

${ }^{1}$ Chinese PLA General Hospital, Medical School of Chinese PLA, Fuxing Road No. 28, Beijing 100853, China

Full list of author information is available at the end of the article
}

C C The Author(s). 2020 Open Access This article is licensed under a Creative Commons Attribution 4.0 International License, which permits use, sharing, adaptation, distribution and reproduction in any medium or format, as long as you give appropriate credit to the original author(s) and the source, provide a link to the Creative Commons licence, and indicate if changes were made. The images or other third party material in this article are included in the article's Creative Commons licence, unless indicated otherwise in a credit line to the material. If material is not included in the article's Creative Commons licence and your intended use is not permitted by statutory regulation or exceeds the permitted use, you will need to obtain permission directly from the copyright holder. To view a copy of this licence, visit http://creativecommons.org/licenses/by/4.0/. The Creative Commons Public Domain Dedication waiver (http://creativecommons.org/publicdomain/zero/1.0/) applies to the data made available in this article, unless otherwise stated in a credit line to the data. 


\section{Background}

Oxygen $\left(\mathrm{O}_{2}\right)$ therapy is widely used in pregnant women. It is estimated that more than $50 \%$ of births with normal oxygenation are given additional $\mathrm{O}_{2}[1]$. Obstetricians and midwives use $\mathrm{O}_{2}$ to improve suspicious fetal heart monitoring patterns or fetal acid-base metabolism. However, the obstetric scientists' understanding of $\mathrm{O}_{2}$ therapy is full of contradictions. The American College of Obstetricians and Gynecologists (ACOG) pointed out the lack of evidence for maternal $\mathrm{O}_{2}$ in Practice Bulletin 106 issued in 2009 [2], based on a Cochrane systematic review [3], the Cochran systematic review stated that there was not enough evidence that maternal prophylactic or therapeutic $\mathrm{O}_{2}$ inhalation could improve fetal acid-base metabolism; however, ACOG supported maternal $\mathrm{O}_{2}$ in Practice Bulletin 116 issued in 2010 [4]. Based on a cohort study of 56 people without a control group [5], the conclusion was reached that $10 \mathrm{~L} / \mathrm{min}$ high-flow mask $\mathrm{O}_{2}$ inhalation could effectively improve the oxygenation status of the fetus. The Society for Maternal-Fetal Medicine has also published a continuous discussion on maternal $\mathrm{O}_{2}$ administration with no consensus [1, 6-9]. Maternal $\mathrm{O}_{2}$ therapy has been written into the latest textbook for obstetrics and gynecology in China [10]. However, this textbook did not provide specific references, nor did it specify the medical indications, concentration or flow range, oxygenation duration, or efficacy of $\mathrm{O}_{2}$ therapy.

In 2017, our trial randomized 443 normal women at the beginning of second stage to get nasal cannula $\mathrm{O}_{2}$ at $2 \mathrm{~L} /$ min or room air. There were no differences between $\mathrm{O}_{2}$ group and control group in the umbilical cord arterial $\mathrm{pH}$ (7.261 versus 7.266), and the study found partial pressure of oxygen $\left(\mathrm{PO}_{2}\right)(\mathrm{mmHg})$ of woman was statistical higher in the $\mathrm{O}_{2}$ group than that of control group (150.0 versus 112.0 $\mathrm{mmHg}$ ) [11]. The present study was a planned secondary analysis of our randomised controlled trial (RCT). Maternal arterial blood $\mathrm{PO}_{2}$ is about $100-110 \mathrm{mmHg}$ in room air; when $\mathrm{PO}_{2}$ reaches about $150 \mathrm{mmHg}$, maternal hemoglobin will be saturated; and when $\mathrm{PO}_{2}$ exceeds $150 \mathrm{mmHg}, \mathrm{O}_{2}$ that continues to increase can only be transported by means of physical dissolution [12]. The purpose of the paper was to evaluate the effect of maternal $\mathrm{O}_{2}$ administration (radial arterial blood $\mathrm{PO}_{2}$ median 150 and interquartile 142.6$156.7 \mathrm{mmHg}$ ) in the second stage on the umbilical venous $\mathrm{PO}_{2}\left(\mathrm{UvPO}_{2}\right)$, the primary outcome was the effect of $\mathrm{O}_{2}$ exposure on $\mathrm{UvPO}_{2}$ and the second outcome was the effect of duration of $\mathrm{O}_{2}$ exposure on $\mathrm{UvPO}_{2}$.

\section{Methods and participants}

This study was carried out at the Sixth Medical Center, Chinese PLA General Hospital, from September 2014 to May 2015 in Beijing, Chin, institutional Review Board Number was $08 / 29 / 2014$. The trial was first posted in clinicaltrials.gov (NCT02221440) 20 August 2014. This manuscript reported adherence to CONSORT guidelines.

The trial included 443 women who had no obstetric complications with category I fetal heart rate (FHR) drawings at the first stage and normal labor at the beginning of second stage. FHR was reviewed as recommended by the ACOG Practice Bulletin category I (normal), category II (indeterminate), category III (abnormal) (Table S1) [2, 4]. Labor was managed according to a consensus from Chinese Medical Association [13]. Participants were 1:1 randomly assigned to get either 2 $\mathrm{L} / \mathrm{min} \mathrm{O}_{2}$ or sham at $0 \mathrm{~L} / \mathrm{min} \mathrm{O}_{2}$ by the nasal cannula from the onset of second stage to delivery. Participants, investigators, and outcomes assessors were blinded to the contents of the nasal cannulas until the conclusion of the study. We assessed the umbilical cord arterial $\mathrm{pH}$ and the FHR pattern from all 443 participants, and reported maternal $2 \mathrm{~L} / \mathrm{min} \mathrm{O}_{2}$ exposure cannot affect the umbilical cord arterial pH or the FHR pattern [11].

All women were invited to participate in radial arterial blood gas analysis, and radial arterial blood samples were obtained in 217 women who voluntarily agreed (these radial samples were non-randomly obtained), paired umbilical cord venous and arterial samples that were also obtained in these participants by one trained research nurse. We selected results from paired arterial and venous samples if venous-arterial $\mathrm{pH}$ difference $>0.02$. The primary outcome for this analysis was $\mathrm{UvPO}_{2}(\mathrm{mmHg})$. These were compared between women with different $\mathrm{O}_{2}$ exposure durations, defined as $<25$ th, $\geqq 25$ th $<50$ th, $\geqq 50$ th $<75$ th, $\geqq 75$ th percentile of the duration of exposure in $\mathrm{O}_{2}$ group, respectively. Outcomes were also compared between room air and different percentiles of $\mathrm{O}_{2}$ exposure duration.

Statistical analysis was performed by the SPSS (IBM SPSS Statistics 22.0). To analyze normal distribution of continuous variables, we used the Kolmogorov-Smirnov test. To analyze normal distributed variables, we used the Student's $t$ test. To analyze abnormal distributed variables, we used the Mann-Whitney $U$ test. Kruskal-Wallis $H$ test was used to determine differences between two or more groups. Data were expressed as median (interquartile range) or mean \pm standard deviation. $P<0.05$ was statistical significance.

\section{Results}

The Fig. S1 showed the recruitment and follow-up of the study.

The Table 1 showed the baseline characteristics of these non-random samples. Of the 443 patients were randomly assigned, 217 participants provided radial arterial blood samples and paired umbilical cord venous and arterial samples, there were 107 patients who were assigned to receive nasal cannula $\mathrm{O}_{2}$ at $2 \mathrm{~L} / \mathrm{min}$ and 110 who were assigned to sham administered. The baseline characteristics were same between $\mathrm{O}_{2}$ group and control group. 
Table 1 Baseline characteristics

\begin{tabular}{|c|c|c|c|}
\hline Outcome & $\begin{array}{l}\text { Oxygen Group } \\
(\boldsymbol{n}=107)\end{array}$ & $\begin{array}{l}\text { Placebo Group } \\
(\boldsymbol{n}=110)\end{array}$ & $P$ \\
\hline Age (y) & $30(27-32)$ & $29(28-31)$ & 0.62 \\
\hline Gestational age (wk) & $40.0(39.3-40.9)$ & $40.0(39.3-40.4)$ & 0.22 \\
\hline Admission BMI $\left(\mathrm{kg} / \mathrm{m}^{2}\right)$ & $25.8(24.5-27.6)$ & $26.6(24.5-28.6)$ & 0.16 \\
\hline Antepartum hemoglobin ( $g / L)$ & $127.1[9.1]$ & $127.2[9.8]$ & 0.93 \\
\hline Duration of first stage (min) & $450(310-590)$ & $450(300-660)$ & 0.76 \\
\hline Duration of second stage (min) & $47(31-67)$ & $42(28-58)$ & 0.29 \\
\hline Maternal pH & $7.367(7.337-7.391)$ & $7.359(7.332-7.381)$ & 0.16 \\
\hline Maternal $\mathrm{PO}_{2}(\mathrm{mmHg})$ & $150.0(142.6-156.7)$ & $112.0(104.8-118.3)$ & $<0.001$ \\
\hline Maternal $\mathrm{PCO}_{2}(\mathrm{mmHg})$ & $26.1[4.1]$ & $27.2[3.4]$ & 0.03 \\
\hline
\end{tabular}

Data are expressed as median (25th-75th percentile) or mean [standard deviation] $B M I$ body mass index

Data from reference 11

Venous-arterial $\mathrm{pH}$ differences were $>0.02$ in all paired arterial and venous samples. There were no differences between the two groups in the umbilical venous $\mathrm{pH}$ (median 7.349, interquartile 7.297-7.397 versus median 7.353, interquartile 7.301-7.381, $P=0.361$ ), the $\mathrm{PO}_{2}$ (median 30.2, interquartile 25.4-35.2 versus median 28.3, interquartile 23.4-35.3, mmHg, $P=0.379$ ), or the $\mathrm{PCO}_{2}$ (median 41.8, interquartile $36.1-47.5$ versus median 42.6 , interquartile 35.3-50.7, mmHg, $P=0.39$ ). There were also no differences between the two groups in the umbilical arterial $\mathrm{PO}_{2}$ (median 18.6, interquartile 15.7-23.2 versus median 19.3, interquartile $14.6-24.7, \mathrm{mmHg}, P=0.299$ ), or the $\mathrm{PCO}_{2}$ (median 54.5, interquartile 44.8-66.7 versus median 58, interquartile 48.3-65.6, $\mathrm{mmHg}, P=0.19$ ). (Table 2).

There were also no differences between different percentiles of $\mathrm{O}_{2}$ exposure duration $(N=26,<25$ th; $N=27$, $\geqq$ 25th $<50$ th; $\mathrm{N}=27, \geqq 50$ th $<75$ th; $\mathrm{N}=27, \geqq 75$ th percentile) and room air in the $\mathrm{UvPO}_{2}(P=0.681)$. (Table 3$)$.

\section{Discussion}

In these non-random blood samples for gas analysis, we showed that maternal $\mathrm{O}_{2}$ exposure at super-physiological levels (radial arterial blood $\mathrm{PO}_{2}$ median 150 and interquartile

Table 2 Paired venous and arterial umbilical cord blood gases

\begin{tabular}{|c|c|c|c|}
\hline Outcome & $\begin{array}{l}\text { Oxygen Group } \\
(\boldsymbol{n}=107)\end{array}$ & $\begin{array}{l}\text { Placebo Group } \\
(\boldsymbol{n}=110)\end{array}$ & $P$ \\
\hline \multicolumn{4}{|c|}{ Umbilical venous gas } \\
\hline $\mathrm{pH}$ & 7.349 (7.297-7.397) & $7.353(7.301-7.381)$ & 0.361 \\
\hline $\mathrm{PO}_{2}(\mathrm{mmHg})$ & $30.2(25.4-35.2)$ & $28.3(23.4-35.3)$ & 0.379 \\
\hline $\mathrm{PCO}_{2}(\mathrm{mmHg})$ & $41.8(36.1-47.5)$ & $42.6(35.3-50.7)$ & 0.39 \\
\hline \multicolumn{4}{|c|}{ Umbilical arterial gas } \\
\hline $\mathrm{pH}[11]$ & 7.264 (7.232-7.299) & $7.266(7.217-7.298)$ & 0.7 \\
\hline $\mathrm{PO}_{2}(\mathrm{mmHg})$ & $18.6(15.7-23.2)$ & $19.3(14.6-24.7)$ & 0.299 \\
\hline $\mathrm{PCO}_{2}(\mathrm{mmHg})$ & $54.5(44.8-66.7)$ & $58(48.3-65.6)$ & 0.19 \\
\hline
\end{tabular}

Data are expressed as median (25th-75th percentile)
$142.6-156.7 \mathrm{mmHg}$ ) during the second stage of labor might not change the $\mathrm{UvPO}_{2}$. There were also no significant differences in the $\mathrm{UvPO}_{2}$ between different percentiles of $\mathrm{O}_{2}$ exposure duration, or between room air and different percentiles of $\mathrm{O}_{2}$ exposure duration. As far as we know, this was the first RCT that $\mathrm{PO}_{2}$ was compared directly between maternal arterial blood and umbilical venous blood.

In general, the maternal arterial blood $\mathrm{PO}_{2}$ is about 100 $110 \mathrm{mmHg}$, while the umbilical venous blood $\mathrm{PO}_{2}$ in term newborns is about $28 \mathrm{mmHg}$ [14]. Although neonatal umbilical cord venous $\mathrm{PO}_{2}$ levels are lower, newborns are not hypoxic. Fetal hemoglobin structure $(\mathrm{HbF}, \alpha 2 \gamma 2)$ is different from that of adults ( $\mathrm{HbA}, \alpha 2 \beta 2)$, and it is easier to bind to $\mathrm{O}_{2}$. The concentration of $\mathrm{HbF}(16.5 \mathrm{~g} / \mathrm{dL})$ is higher than $\mathrm{HbA}(12.5 \mathrm{~g} / \mathrm{dL})$. Therefore, Fetal umbilical venous $\mathrm{O}_{2}$ content is at the same level as adult arterial blood $\mathrm{O}_{2}$ content $[15,16]$. In human blood, $98.5 \% \mathrm{O}_{2}$ is transported by means of binding to hemoglobin, and $1.5 \% \mathrm{O}_{2}$ is transported by means of physical dissolution [12]. Maternal inhalation of $\mathrm{O}_{2}$ will significantly increase the $\mathrm{PO}_{2}$ of her arterial blood. Polvi et al. [17] found that inhaling 50\% $\mathrm{O}_{2}$ can make the maternal $\mathrm{PO}_{2}$ exceed $200 \mathrm{mmHg}$, and inhaling $100 \% \mathrm{O}_{2}$ can make the maternal $\mathrm{PO}_{2}$ exceed 300 $\mathrm{mmHg}$ in only $5 \mathrm{~min}$. When $\mathrm{PO}_{2}$ exceeds $150 \mathrm{mmHg}$, hemoglobin has become saturated, and $\mathrm{O}_{2}$ that continues to increase can only be transported by means of physical dissolution [12]. Physically dissolving transportation method is very inefficient, at standard atmospheric pressure, for every one $\mathrm{mmHg}$ increase in $\mathrm{PO}_{2}$, the dissolved $\mathrm{O}_{2}$ per liter of blood only increases by $0.03 \mathrm{ml}$ [12].

However, $\mathrm{PO}_{2}$ cannot be increased indefinitely to increase physical dissolution, because data from humans and experimental animals show that $\mathrm{O}_{2}$ at the superphysiological level would trigger oxidative stress and oxidative damage in the mother-fetus [18-20]. Khaw et al. [20] randomized 44 women undergoing spinal canal anesthesia and found that inhaling $60 \% \mathrm{O}_{2}$ could significantly increase 
Table 3 The effect of duration of oxygen exposure on umbilical cord venous $\mathrm{PO}_{2}$

\begin{tabular}{|c|c|c|c|c|c|c|}
\hline \multirow[t]{2}{*}{ Outcomes } & \multirow[t]{2}{*}{ Air $(\boldsymbol{N}=110)$} & \multicolumn{4}{|c|}{ Percentiles of oxygen exposure duration } & \multirow[t]{2}{*}{$P$} \\
\hline & & $<25$ th $(\boldsymbol{N}=26)$ & $\begin{array}{l}\geqq 25 \text { th }<50 \text { th }(\boldsymbol{N}= \\
27)\end{array}$ & $\begin{array}{l}\geqq 50 \text { th }<75 \text { th }(\boldsymbol{N}= \\
27)\end{array}$ & $\geqq 75$ th $(\boldsymbol{N}=27)$ & \\
\hline $\begin{array}{l}\text { Umbilical cord venous } \mathrm{PO}_{2} \\
(\mathrm{mmHg})\end{array}$ & $28.3(23.4-35.3)$ & $30.3(25.7-35.1)$ & $27.4(25.3-34.2)$ & $31.6(27.7-35.5)$ & $29.4(23.2-34.8)$ & 0.681 \\
\hline $\begin{array}{l}\text { Maternal radial arterial } \mathrm{PO}_{2} \\
(\mathrm{mmHg})\end{array}$ & $112.0(104.8-118.3)$ & $150.4(142.7-156.3)$ & $151.8(142.8-158.8)$ & $150(146.5-156.1)$ & $\begin{array}{l}147.5(142.5- \\
156)\end{array}$ & 0.000 \\
\hline
\end{tabular}

Data are expressed as median (25th-75th percentile)

the lipid peroxides, a marker of oxidative stress, including maternal arterial and neonatal umbilical arterial 8isoprostane, malondialdehyde, and hydroperoxide. It is currently inferred that oxidative stress can cause vasoconstrictive effects [21]. Smit et al. [22] systematically reviewed 60 experimental animal studies and found that excessively high $\mathrm{PO}_{2}$ can cause vasoconstriction in vivo and in vitro, and there was a clear dose dependent effect. Smit et al. [23] also systematically reviewed 33 clinical studies and found that excessively high $\mathrm{PO}_{2}(234-617 \mathrm{mmHg})$ can increase vascular resistance by $11-16 \%$ in healthy people and $24.6 \%$ in patients with heart failure, and can decrease cardiac output by $10.2 \%$ in healthy people, $9.6 \%$ in patients with coronary heart disease, and $15.2 \%$ in patients with heart failure.

There were only four RCTs assessed the effect of maternal prophylactic or therapeutic inhalation of $\mathrm{O}_{2}$ on fetal acid-base metabolism during the second stage or active period of labor. These randomised trial showed $\mathrm{O}_{2}$ therapy did not improve fetal acid-base metabolism and even increased the risk of fetal acidosis. Our trial randomized 443 normal women and found there were no significant differences between $2 \mathrm{~L} / \mathrm{min} \mathrm{O}_{2}$ group and room air group in the abnormal umbilical cord arterial $\mathrm{pH}$ values, and found in 217 non-random samples maternal $\mathrm{O}_{2}$ exposure at super-physiological levels (median arterial blood $\mathrm{PO}_{2} 150 \mathrm{mmHg}$ ) cannot increase the umbilical cord venous $\mathrm{PO}_{2}$ (30.2 versus $28.3 \mathrm{mmHg}$ ) [11]. Raghuraman et al. [24] randomized 114 women with nonreassuring FHR tracings and found there were no significant differences between $10 \mathrm{~L} / \mathrm{min} \mathrm{O}_{2}$ group and room air group in the abnormal umbilical cord arterial $\mathrm{pH}$ and lactate values, and they even found long durations of $\mathrm{O}_{2}$ exposure were associated with lower in the $\mathrm{UvPO}_{2}$ (32.5 versus $25.5 \mathrm{mmHg}$ ). Thorp et al. [25] randomized 86 normal women and found maternal $10 \mathrm{~L} /$ min $\mathrm{O}_{2}$ exposure were associated with more umbilical cord arterial $\mathrm{pH}<7.2$ events $(9 / 41$ versus $2 / 44)$, and found this $\mathrm{O}_{2}$ exposure cannot increase the in the $\mathrm{UvPO}_{2}$ (31.2 versus $29.7 \mathrm{mmHg}$ ). Sirimai et al. [26] randomized 160 normal women and also found more umbilical cord arterial $\mathrm{pH}<7.2$ events under maternal $\mathrm{O}_{2}$ exposure with no statistical difference (8/80 versus 3/ 80 ). Our results did not conflict with previous studies. In
Raghuraman et al. [24] and Thorp et al. [25] trials, the $\mathrm{O}_{2}$ flow rate was $10 \mathrm{~L} / \mathrm{min}$ and the fraction of inspired $\mathrm{O}_{2}\left(\mathrm{FIO}_{2}\right)$ was about $60-80 \%$, Thorp et al. [25] showed high level $\mathrm{O}_{2}$ exposure had no effect on $\mathrm{UvPO}_{2}$, and Raghuraman et al. [24] even showed longer high level $\mathrm{O}_{2}$ exposure was associated with lower $\mathrm{UvPO}_{2}$. The effects of super-physiological $\mathrm{O}_{2}$ induced vasoconstriction would reduce blood perfusion of tissue to a greater extent than the little maternal arterial $\mathrm{O}_{2}$ content rise [11]. In our study, the $\mathrm{O}_{2}$ flow rate was $2 \mathrm{~L} / \mathrm{min}$ and the fraction of inspired $\mathrm{O}_{2}\left(\mathrm{FIO}_{2}\right)$ was about $30 \%$, we found low level $\mathrm{O}_{2}$ exposure had no effect on $\mathrm{UvPO}_{2}$ and the duration of exposure had no effect on $\mathrm{UvPO}_{2}$ (Tables 2 and $3)$. These three showed maternal $\mathrm{O}_{2}$ exposure did not increase $\mathrm{UvPO}_{2}$.

This secondary analysis has important limitations. First, we compared the baseline characteristics of all women and there were no significant differences between most two comparisons except antepartum hemoglobin in the oxygen group (Table S2). However, radial arterial blood samples and umbilical cord blood samples were non-randomly obtained in those nonrandom women who voluntarily agreed immediately after delivery. Further study is very likely to have an important impact on this analysis, which provided low quality evidence with a high selection bias. Second, the $\mathrm{PO}_{2}$ in $\mathrm{O}_{2}$ group was median 150, interquartile 142.6156.7, and range $135.1-177 \mathrm{mmHg}$. The minimum value was only $135.1 \mathrm{mmHg}$ and only half women exceeded $150 \mathrm{mmHg}$ in the real world. To observe the effect of super-physiological $\mathrm{O}_{2}$, future study should make the $\mathrm{PO}_{2}$ exceed at least $150 \mathrm{mmHg}$ in all women in the $\mathrm{O}_{2}$ group.

\section{Conclusion}

We conclude that maternal $\mathrm{O}_{2}$ exposure at superphysiological levels (median arterial blood $\mathrm{PO}_{2} 150$ $\mathrm{mmHg}$ ) in normal labor may not change the $\mathrm{UvPO}_{2}$. Further studies in the form of RCTs would be needed to assess change in $\mathrm{UvPO}_{2}$ with maternal supplemental oxygenation at super-physiological levels. Our data is insufficient to change practice of maternal supplementation of $\mathrm{O}_{2}$ at this time. 


\section{Supplementary information}

Supplementary information accompanies this paper at https://doi.org/10. 1186/s12884-020-03212-3.

Additional file 1: Figure S1. Flow diagram of trial recruitment and follow up.

Additional file 2: Table S1. Three-tiered fetal heart rate interpretation system.

Additional file 3: Table S2. Baseline characteristics of all women and non-random women.

\section{Abbreviations}

ACOG: American College of Obstetricians and Gynecologists; $\mathrm{PO}_{2}$ : Arterial partial pressure of oxygen; FHR: Fetal heart rate; $\mathrm{O}_{2}$ : Oxygen;

$\mathrm{RCT}$ : Randomised controlled trial; $U \mathrm{PO}_{2}$ : Umbilical cord venous $\mathrm{PO}_{2}$

\section{Acknowledgements}

We acknowledge the research nurses and research midwives from our department for their efforts.

\section{Authors' contributions}

$Y C$ and $X X$ were involved in study design/planning. YC and WJ performed data collection/entry. LC and AW performed data analysis/statistics. YC, WJ, and $Y Y$ interpreted the data. YC and WJ prepared the paper. LC, YY and XX performed literature analysis/search. WJ and LC revised the manuscript. All authors have read and approved the manuscript.

\section{Funding}

This work were supported by a grant from the Beijing Municipal Science \& Technology Commission (Grant No. Z181100001718004) and a grant from the National Natural Science Foundation of China (Grant No. 8200060383). These study funders had no involvement in the research design, data collection, interpretation of the data, or publication.

\section{Availability of data and materials}

The dataset used in the present study is available from the corresponding author upon reasonable request.

\section{Ethics approval and consent to participate}

Institutional Review Board Project \# No. 08/29/2014 was approved on 29 August 2014 by the Sixth Medical Center, Chinese PLA General Hospital Ethics Committee (former Navy General Hospital). All study participants gave verbal informed consent before or during the first stage, this was approved by the Chinese PLA General Hospital Ethics Committee as oxygen inhalation was a routine clinical practice in China.

\section{Consent for publication}

Not applicable.

\section{Competing interests}

The authors declare they have no competing interests.

\section{Author details}

${ }^{1}$ Chinese PLA General Hospital, Medical School of Chinese PLA, Fuxing Road No. 28, Beijing 100853, China. ²Department of Obstetrics and Gynaecology, Sixth Medical Center, Chinese PLA General Hospital, Beijing, China. ${ }^{3}$ Department of Anaesthesia, Chaoyang Chinese Traditional and Western Medicine Emergency Medical Center, Beijing, China. ${ }^{4}$ Department of Obstetrics and Gynaecology, First Medical Center, Chinese PLA General Hospital, Beijing, China.

Received: 14 April 2020 Accepted: 26 August 2020

Published online: 04 September 2020

\section{References}

1. Hamel MS, Anderson BL, Rouse DJ. Oxygen for intrauterine resuscitation: of unproved benefit and potentially harmful. Am J Obstet Gynecol. 2017; 211(2):124-7.
2. American College of Obstetricians and Gynecologists. Practice bulletin no. 116: management of intrapartum fetal heart rate tracings. Obstet Gynecol. 2010;116(5):1232-40.

3. Fawole B, Hofmeyr GJ. Maternal oxygen administration for fetal distress. Cochrane Database Syst Rev. 2012;12:CD000136.

4. American College of Obstetricians and Gynecologists. Practice bulletin no. 106: Intrapartum fetal heart rate monitoring: nomenclature, interpretation, and general management principles. Obstet Gynecol. 2009;114(1):192-202.

5. Simpson KR, James DC. Efficacy of intrauterine resuscitation techniques in improving fetal oxygen status during labor. Obstet Gynecol. 2005;105:1362-8

6. Garite TJ, Nageotte MP, Parer JT. Should we really avoid giving oxygen to mothers with concerning fetal heart rate patterns? Am J Obstet Gynecol. 2015:212:459-60 459.e1.

7. Hamel MS, Hughes BL, Rouse DJ. Whither oxygen for intrauterine resuscitation? Am J Obstet Gynecol. 2015;212:461-2 461.e1.

8. Doyle JL, Silber AC. Maternal oxygen administration for intrauterine resuscitation. Am J Obstet Gynecol. 2015:212(3):409.

9. Michael GR, Kevin EA. Maternal oxygen use during labor. Am J Obstet Gynecol. 2015;212(3):410.

10. Xie X, Kong B, Duan T. Ninth edition: obstetrics and gynecology. Beijing: People's Health Publishing House; 2018.

11. Qian G, Xu X, Chen L, Xia S, Wang A, Chuai Y, Jiang W. The effect of maternal low flow oxygen administration during the second stage of labour on umbilical cord artery pH: a randomised controlled trial. BJOG. 2017;124:678-85.

12. Wang T. Ninth edition: physiology. Beijing: People's Health Publishing House; 2018.

13. Chinese Medical Association. Expert consensus on new labor standards and treatment (2014). Zhonghua fu chan ke za zhi. 2014;49(07):486.

14. Meschia G. Fetal oxygenation and maternal ventilation. Clin Chest Med. 2011;32:15-9.

15. Milman N, Bergholt T, Byg K, Eriksen L, Hvas A. Reference intervals for hematological variables during normal pregnancy and postpartum in 434 healthy Danish women. Eur J Haematol. 2007;79:39-46.

16. Beaton $\mathrm{GH}$. Iron needs during pregnancy: do we need to rethink our targets? Am J Clin Nutr. 2000;72(Suppl):265-71S.

17. Polvi HJ, Pirhonen JP, Erkkola RU. The hemodynamic effects of maternal hypo and hyper oxygenation in healthy term pregnancies. Obstet Gynecol. 1995:86:795-9.

18. Suzuki S, Yoneyama Y, Sawa R, Murata T, Araki T, Power GG. Changes in fetal plasma adenosine and xanthine concentrations during fetal asphyxia with maternal oxygen administration in ewes. Tohoku J Exp Med. 2000;192:275-81.

19. Yamada T, Yoneyama Y, Sawa R, Araki T. Effects of maternal oxygen supplementation on fetal oxygenation and lipid peroxidation following a single umbilical cod occlusion in fetal goats. J Nippon Med Sch. 2003;70:165-71.

20. Khaw KS, Wang CC, Ngan Kee WD, Pang CP, Rogers MS. Effects of high inspired oxygen fraction during elective cesarean section under spinal anesthesia on maternal and fetal oxygenation and lipid peroxidation. $\mathrm{Br} \mathrm{J}$ Anaesth. 2002:88:18-23.

21. Steinhorn RH, Lakshminrusimha S. Oxygen and pulmonary vasodilation: The role of oxidative and nitrosative stress. Semin Fetal Neonatal Med. 2020; 25(2):101083. Epub 2020 Jan 16.

22. Smit B, Smulders YM, Eringa EC, et al. Effects of hyperoxia on vascular tone in animal models: systematic review and meta-analysis. Crit Care. 2018;22(1): 189.

23. Smit B, Smulders YM, van der Wouden JC, Oudemans-van Straaten HM, Spoelstra-de Man AME. Hemodynamic effects of acute hyperoxia: systematic review and meta-analysis. Crit Care. 2018;22(1):45..

24. Raghuraman N, Wan L, Temming LA, Woolfolk C, Macones GA, Tuuli MG, Cahill AG. Effect of oxygen vs room air on intrauterine fetal resuscitation a randomized noninferiority clinical trial. JAMA Pediatr. 2018;172(9):818-23.

25. Thorp JA, Trobough T, Evans R, Hedrick J, Yeast JD. The effect of maternal oxygen administration during the second stage of labor on umbilical cord blood gas values: a randomized controlled prospective trial. Am J Obstet Gynecol. 1995;172:465-74.

26. Sirimai $K$, Atisook R, Boriboonhirunsam D. The correlation of intrapartum maternal oxygen administration and umbilical cord blood gas values. Acta Obstet Gynecol Scand Suppl. 1997;76:90.

\section{Publisher's Note}

Springer Nature remains neutral with regard to jurisdictional claims in published maps and institutional affiliations. 